\title{
Study on the Behavior of Dental Alloy CoCrWNbMoV in Artificial Saliva
}

\begin{abstract}
ADRIAN ALEXANDRU1', RAMONA CIMPOESU1', ANCA MELIAN²*, MIHAELA SALCEANU²
${ }^{1}$ Gheorghe Asachi Technical University of lasi, Faculty of Materials Science and Engineering, 67 D. Mangeron Blvd., 700050, Iasi, Romania

${ }^{2}$ Grigore T. Popa University of Medicine and Pharmacy, Faculty of Dental Medicine, 15 Mihail Kogãlniceanu Str., 700454 lasi, Romania

Dental materials represent an important market worldwide. For solutions that are currently financially acceptable, CoCr or CoCrMo alloys have been an affordable option for all dental technicians. Constant improvements in the properties of this alloy such as corrosion resistance and hardness have been pursued. In this paper are presented some experimental results obtained from the electro-corrosion resistance analysis of the CoCrWNbMoV alloy in two electrolyte solutions made from artificial saplings Afnor and respectively Duffo Quezada. Following electro-corrosion resistance tests, the surface of the alloy was characterized by optical and electron microscopy (OM and SEM) and chemical dispersion X-ray (EDS) analysis.
\end{abstract}

Keywords: dental materials, corrosion resistance, CoCrWNbMoV, EDS

Implantable materials, including dental alloys, due to their composition and structure, react relatively easily in the oral environment undergoing a process of chemical, electrochemical and biological corrosion degradation [13]. The most important influence in this case is electrochemical corrosion. The effects of corrosion can occur after an indefinite time since implantation into the oral cavity or other parts of the body, manifested first by altering the color of the alloy, then reaching up to cracks or fractures of gnatoprotective apparatus, in especially at the extensions level [4]. In the teeth there are pigments (which sometimes extend to the adjacent mucosa), cariogenesis and even corono-radical destruction. Local symptoms are manifested by metallic taste, nausea, burns, due to the release of metal ions from dental alloys and secondary corrosion products [5-7].

Even mucosal lesions with malignant potential may occur. The appearance of oral galvanism, apart from initiating and/or accelerating the corrosion of metallic alloys, produces allergic effects that may cause the appearance of allergic dermatitis located in different body areas [8]. Corrosion is included in the topic of biocompatibility because it is an important factor in the release of metallic ions from dental alloys. Knowing the factors that can influence the characteristics of the alloys during the technological stages of casting and processing, measures can be taken to improve mechanical and chemical parameters by improving the microstructure, ensuring optimal conditions for integration of the gnatato-prosthetic devices into the structures of the dental system [9-12]. Lately, new alloys have appeared, the advertising and price of which makes it difficult for the practitioner to choose the best alloy from a functional, biomechanical and biocompatible point of view [13]. Complete removal of metallic alloys from dentistry and promotion of completely non-metallic alternatives - whole ceramic systems (Cerestore, Cerapearl, Dicor, Hi-Ceram, In-Ceram, Empress) or ceromer systems (Targis/VeCtris) limited to us in the country due to prohibitive prices [14]. Until the final disposal of metals and dental alloys has to be taken into account factors influencing the structure and, implicitly, their properties [15-18].

In this article the behavior of an experimental alloy based on CoCrWNbMoV in two artificial saliva with different compozition and simillar $\mathrm{pH}$ was evaluate by electrocorrosion point of view.

\section{Experimental part}

Experimental samples were made in metallurgical laboratory of Materials Science and Engineering Faculty from lasi. The chemical composition of the complex alloy is (wt/at \%): Co: (60.7-63.7) , Cr: (22.7-27.0), W: (8.7-2.9), $\mathrm{Nb}:(3.2-2.1)$, Fe: (0.1-0.2) , Mo: (2.1-1.4), V: (1.8-2.1) and

\begin{tabular}{|c|l|c|c|}
\hline $\begin{array}{c}\text { SOLUTION } \\
\text { (artificial saliva) }\end{array}$ & \multicolumn{2}{|c|}{ COMPOZITION (g/L) } & pH \\
\hline & $\mathrm{NaCl}$ & 0.700 & \\
& $\mathrm{KCl}$ & 1.200 & \\
AFNOR & $\mathrm{Na}_{2} \mathrm{HPO}_{4} \cdot \mathrm{H}_{2} \mathrm{O}$ & 0.26 & $6.7-8$ \\
& $\mathrm{NaHCO}_{3}$ & 1.500 & \\
& $\mathrm{KSCN}$ & 0.330 & \\
& $\mathrm{Uree}$ & 1.330 & \\
\hline \multirow{5}{*}{ DUFFO-QUEZADA } & $\mathrm{NaCl}$ & 0.600 & \\
& $\mathrm{KCl}$ & 0.720 & \\
& $\mathrm{CaCl}_{2} \cdot 2 \mathrm{H}_{2} \mathrm{O}$ & 0.220 & \\
& $\mathrm{KH}_{2} \mathrm{PO}_{4}$ & 0.680 & 6.5 \\
& $\mathrm{Na}_{2} \mathrm{HPO}_{4} \cdot 12 \mathrm{H}_{2} \mathrm{O}$ & 0.856 & \\
& $\mathrm{KSCN}$ & 0.060 & \\
& $\mathrm{KHCO}_{3}$ & 1.500 & \\
& citric acid & 0.030 & \\
\hline
\end{tabular}

Table 1

CHEMICAL COMPOSITION OF ELECTROLYTE SOLUTION

*email:meliananca@yahoo.com 
Si: (0.9-0.9). The material structure was obtain after mechanical grinding of the surface, polish and chemical etching using royal water solution $\left(\mathrm{HNO}_{3}+\mathrm{HCl}\right)$ at $60^{\circ} \mathrm{C}$. Two cylindrical samples were mechanically polished till 2000 grid and experimental electrodes, in teflon, were made for electro-corrosion resistance experiments [19]. A potentiostat equipment (PGP 201) with a three electrodes cell was used for tests in two different electrolyte solutions of artificial saliva (table 1).

After the electrochemical experiments (linear and cyclic potentiometry) the material was cleaned by sonication for $60 \mathrm{~min}$ in technical alcohol [18]. The experimental samples surface was analyzed using SEM equipment (scanning electron microscopy with VegaTescan LMH II, VegaT software for 2D characterization) and EDAX detector (X-ray energy dispersive spectroscopy, Bruker type, Esprit software) for structural and chemical analyses [19-22].

\section{Results and discussions}

Surface of the experimental samples was analyzed after the electro-corrosion resistance test.

The linear polarization curves were plotted within the potential range: $-0.8 \ldots+1 \mathrm{~V}$, using a scanning speed of 1 $\mathrm{mV} / \mathrm{s}$. The representation of the linear and cyclic polarization curves in the coordinates: Current/potential density (fig. 1a-b), allows the highlighting of corrosion potential (Ecor) and of corrosion currents (jcor). Also, chemical changes occurring in the system, such as oxidation passivation, metal dissolution, hydrogen and water reduction (hydrogen and oxygen release), corrosion by dots, the existence of secondary anodic or cathodic processes through which transformations of ionic species from electrolyte take place [23-26]. The corrosion rate may correlate with the intensity of the corrosion current or the current density based on Faraday's law. For both experimental cases corrosion rates were obtained in the order of tens of micrometers per year.

In the case of the corrosion process described by the curve in figure $1 \mathrm{~b}$ the metal surface is unaffected by the corrosion medium between the corrosion potential and the breakthrough potential. At potentials larger than the penetration potential, some portions will suffer severe localized attacks and the corrosion rate will increase sharply. In both cases a generalized corrosion of the material surface with a rapid passivation of the material is observed.
The cathode curve, figure $1 b$, follows the same path as the anode curve - generating a very low hysteresis loop, almost non-existent, ie the current densities in the passive region are similar to those recorded during direct (anodic) scanning at the same potential. The absence of a current loop is directly related to the stability of the corrosion points and the competition between diffusion and dissolution in localized corrosion sites. An open corrosion point is subjected to very fast semi-spherical diffusion. In order to maintain aggressive environmental conditions, the dissolution rate at the corrosion point and hydrolysis following dissolution should be high enough to overcome the diffusion processes [27-28]. For both situations, no aggressive surface attack is observed because it quickly passivated and the surface oxide layer resists the potential changes occurring during the experiment. In the initial portion of the cathode branch (reverse scanning) the dissolution power of the compounds decreases and the corrosion products do not have enough time to diffuse outward.

The main parameters of the corrosion process $\left(\mathrm{E}_{0}\right.$ and jcor) obtained by processing the linear polarization curves are centralized in table 2. The corrosion current thus determined is in fact the corrosion current occurring at the metal/corrosive environment interface when the metal is immersed in the solution and can not be measured directly by electrochemical methods. This is actually a corrosion current instantly.

The constant values of the current density observed at different potential values are an indication that the alloy does not present pitting corrosion. For both experimental cases corrosion rates were obtained in the order of tens of micrometers per year. By analyzing the values of polarization resistance, corrosion current and corrosion rate, we can state that electrochemically the alloy behaves similarly in the two electrolyte media regardless of the differences between their chemical compositions.

SEM and EDS analyses were made to evaluate the existence of non-metallic inclusions. From the electronic and optical microscopy analysis (fig. 2) obtained at the 1000X magnification power for the CoCrW NbMoV complex experimental alloy, a dendritic structure specific to cast alloys with finely dendritic, well-developed and oriented dendrites, as well as a precipitated interdendritic phase in a small amount.
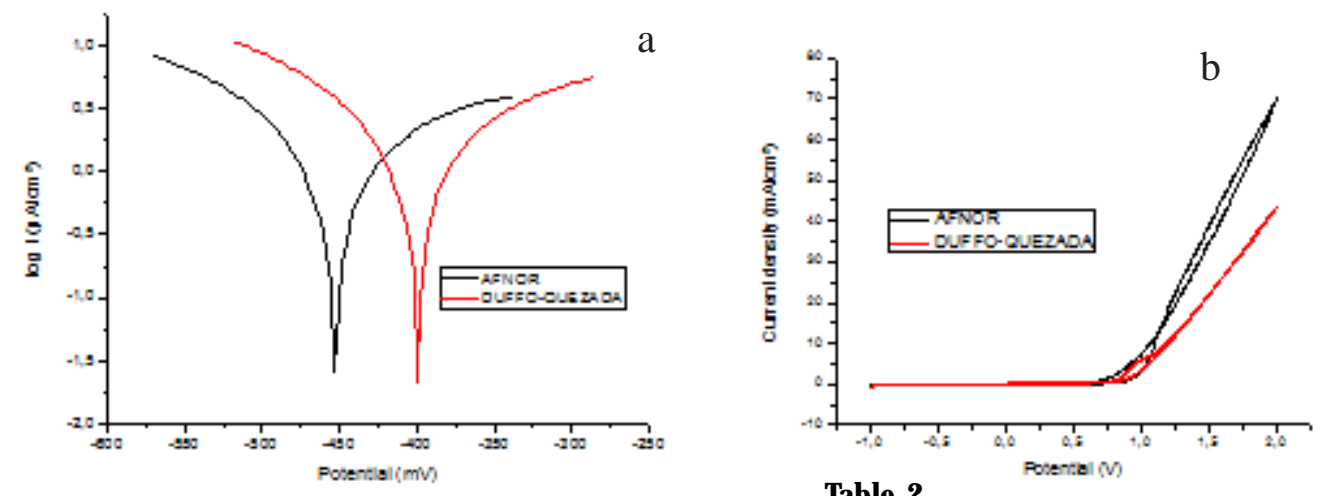

Fig. 1. Electro-corrosion resistance test:

a) Tafel diagram; b) Cyclic potentiometry

ELECTRO-CHEMICAL CORROSION TEST PARAMETERS

\begin{tabular}{|c|c|c|c|c|c|c|}
\hline Sample & $\begin{array}{c}\mathrm{E}_{0} \\
\mathrm{mV}\end{array}$ & $\begin{array}{c}\mathrm{b}_{\mathrm{z}} \\
\mathrm{mV}\end{array}$ & $\begin{array}{c}\mathrm{b}_{\mathrm{e}} \\
\mathrm{mV}\end{array}$ & $\begin{array}{c}\mathrm{R}_{\mathrm{p}} \\
\text { kohm. } \mathrm{cm}^{2}\end{array}$ & $\begin{array}{c}\mathrm{J}_{\text {cos }} \\
\mu \mathrm{A} / \mathrm{cm}^{2}\end{array}$ & $\begin{array}{c}\mathrm{V}_{\text {cor }} \\
\mu \text { m/year }\end{array}$ \\
\hline Afnor & -452.7 & 373.8 & -189.3 & 22.51 & 2.02 & 82.39 \\
\hline Duffo-Quezada & -399.6 & 215.7 & -152.7 & 18.13 & 1.89 & 77.38 \\
\hline
\end{tabular}




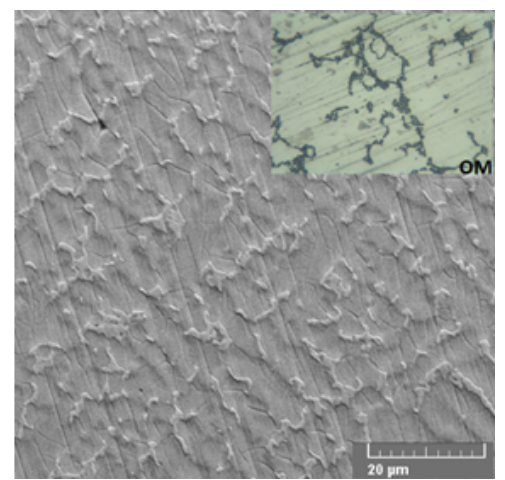

Fig. 2. Initial surface state SEM image and OM in detail

In figure 3 are presented SEM microstructural surface analyze images after the electro-chemical resistance tests in Afnor solution (fig. 3a and b) and Duffo-Quezada solution (fig. $3 c$ and d). In the case of the sample analyzed in Afnor solution a generalized corundum surface is observed and completely covered with a layer of compounds. The layer formed, beginning as a passivation layer, has a structure similar to the structure of the experimental alloy (fig. 2) because both the matrix and the dendrites formed different corrosion compounds, thus retaining the original structure.

It can be noticed that the layer formed on the surface of the alloy after the test carried out in the artificial solution Afnor is not continuous, at least at the surface (fig. 3b), the matrix of the material forming specific compounds among which some of the compounds characteristic of existing dendrites have grown, or only the structure dentrites have remained.

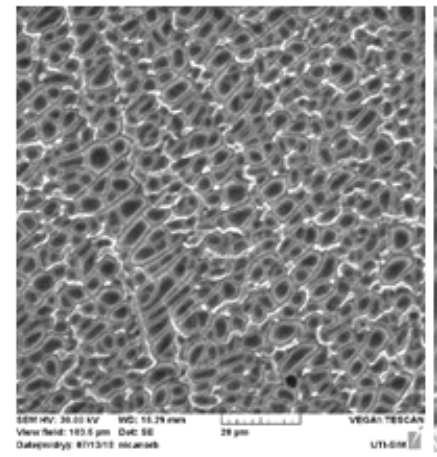

a)

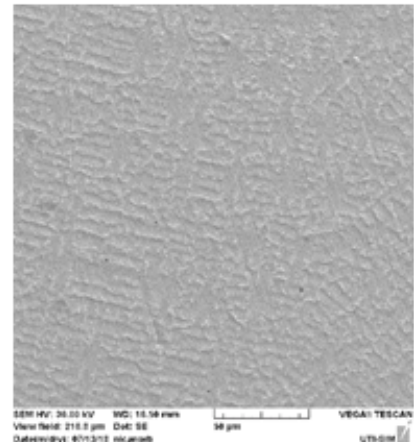

c)

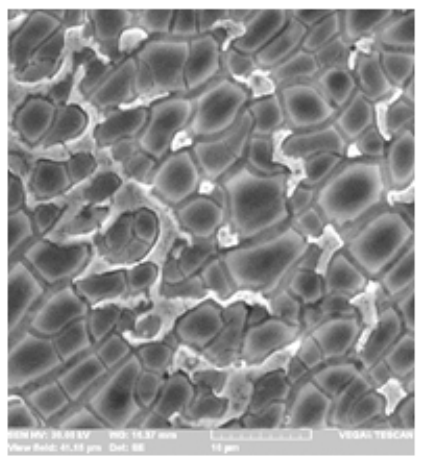

b)

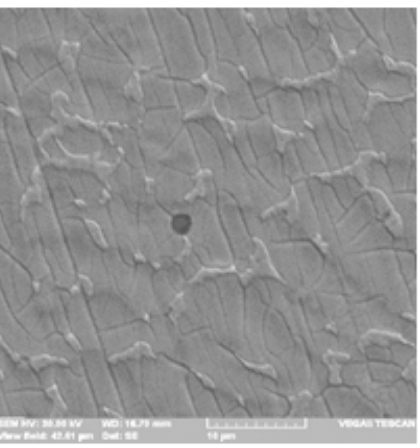

d)

Fig. 3. SEM structural surface analyze after the electro-chemical resistance tests: a. and b. Afnor solutions; c. and d. Duffo-Quezada solutions
In the case of the behavior of the CoCrWNbMoV alloy in the second electrolyte solution, namely the Duffo-Quezada artificial saliva solution (fig. $3 c$ and d) no reaction compounds are formed on the surface of the alloy, butonly an alloy structure is evidenced by an attack selective of the component phases. There is also the appearance of additional oxides to the passivation layer formed over the entire surface of the alloy.

The chemical composition of the surface alloy after the electrocorosion resistance tests is given in table 3 . The results were obtained by chemical EDS analysis on a surface area of $4 \mathrm{~mm}^{2}$. In the table are given the percentage values of each element determined by the Automatic List mode for mass percentages and atomic percentages. Also, the error of the EDS detector characteristic of each chemical element is also presented.

From the analysis of the chemical compositions obtained on the surface of the alloy after the electro-corrosion test and cleaning in an ultrasonic bath, the following were observed:

-both surfaces were oxidized with a percentage increase for Duffo-Quezada solution;

-in the case of the test carried out in Afnor on the surface of the alloy, stable compounds formed of sodium and chlorine appeared, which were notidentified on the surface of the alloy tested in the Duffo-Quezada solution;

-with respect to the initial chemical composition, cobalt has lower percentages being replaced by the percentage of oxygen at the surface of the material;

-the passivation layer formed is largely based on chromium oxide, the chromium element varies very little in percentage compared to the percentage of the initial alloy and its superior corrosion resistance is well known;

-the corrosion resistance is also improved by inserting the tungsten element in the alloy composition, which exhibits higher percentages than the initial alloy after passivation, $9.8 \%$ wt in Afnor and $10.2 \%$ wt in DuffoQuezada due to the percentage decrease of the other elements, especially the cobalt.

All the alloying elements introduced to increase the corrosion resistance, $\mathrm{W}, \mathrm{Nb}$ and $\mathrm{V}$ have retained the percentages of their retaining values in the surface layer and that the passivation layer formed is one of several oxides, all with high corrosion resistance. In figure 4 is presented the distribution of main chemical elements from the experimental alloy surface $a$ ) and $b$ ) after the electrocorrosion testin artificial saliva Afnor and c) and d) in DuffoQuezada. The distributions of the main elements identified on the surface confirm the surface oxidation and the generalized corrosion.

The passivation layer formed on the surface is compact and even after the electro-corrosion test in Afnor the surface present compounds based on ixides and salts under this compounds an complex oxides layer exist to cover and protect the alloy surface.

Generalized corrosion of dental alloys is important for passivation of the alloy surface and for maintaining the integrity of the passivation layer.

Table 3

CHEMICAL COMPOSITION OF THE SURFACE AFTER THE ELECTRO-CHEMICAL TEST

\begin{tabular}{|c|c|c|c|c|c|c|c|c|c|c|c|c|c|c|c|c|c|c|}
\hline \multirow{2}{*}{ Chem. Elem. } & \multicolumn{2}{|c|}{$\mathrm{C}_{0} \%$} & \multicolumn{2}{|c|}{ Cr\% } & \multicolumn{2}{|c|}{ W\% } & \multicolumn{2}{|c|}{ Nb\% $\%$} & \multicolumn{2}{|c|}{$0 \%$} & \multicolumn{2}{|c|}{$\mathrm{V} \%$} & \multicolumn{2}{|c|}{$\mathrm{Fe} \%$} & \multicolumn{2}{|c|}{$\mathrm{Cl} \%$} & \multicolumn{2}{|c|}{$\mathrm{Na} \%$} \\
\hline & wt & at & wt & at & wt & at & wt & at & wt & at & wt & at & wt & at & wt & at & wt & at \\
\hline Afnor & 53 & 45.1 & 22.1 & 21.4 & 9.8 & 2,7 & 3 & 1.6 & 6.3 & 19,9 & 1.9 & 1.9 & 0.3 & 0.3 & 0.5 & 0.7 & 2.9 & 6.4 \\
\hline Duffo-Quezada & 50.9 & 39.8 & 21.8 & 19.3 & 10.2 & 2.6 & 2.8 & 1.4 & 12,11 & 34,9 & 1.9 & 1.8 & 0.2 & 0.2 & - & - & - & - \\
\hline EDS error & & 1 & & & 0 & & & & 1, & & & & & & & & & 3 \\
\hline
\end{tabular}




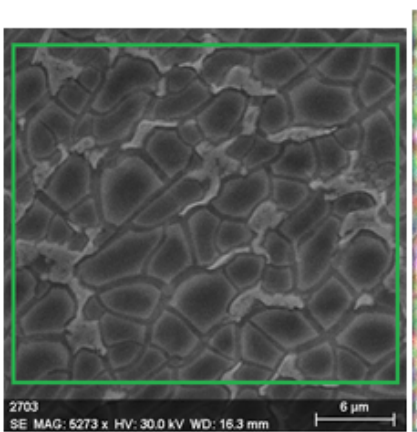

a)

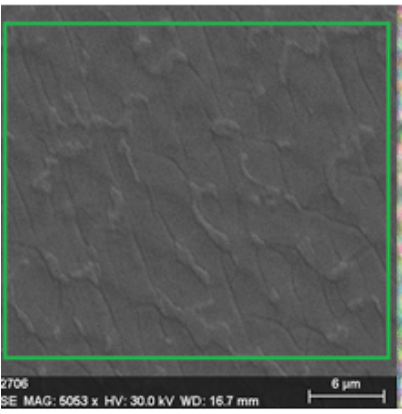

c)

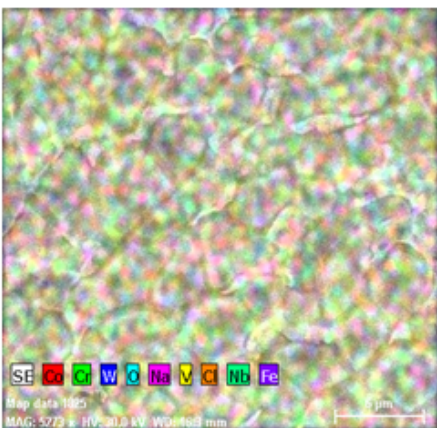

b)

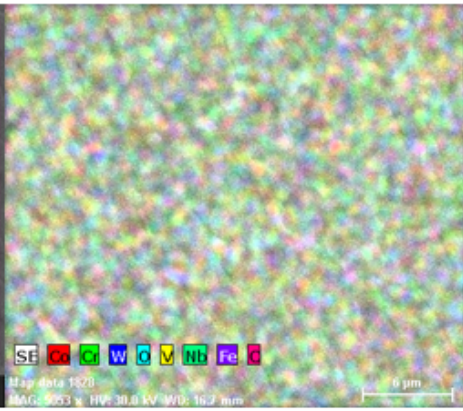

d)
Fig. 4. Distribution of main chemical elements from the experimental alloy surface: $a$. and $b$. after the electro-corrosion test in artificial saliva Afnor; $c$. and d. after the electro-corrosion test in artificial saliva Duffo-Quezada

\section{Conclusions}

The complex CoCrWNbMoV alloy exhibits very good behavior in electrolyte solutions made up of artificial saplings Afnor and Duffo-Quezada. Electro-corrosion resistance tests confirm passivation of the alloy surface, in both cases, by forming a complex oxide layer based on chromium, tungsten, niobium and vanadium. The corrosion rate is similar in both cases and is in the order of a few dozen micrometers per year. Cyclic potentiometry curves and surface SEM analysis confirm the trend of generalized surface corrosion. Surface chemical analyzes confirm the formation of salt deposits over the surface oxide layer in the experiments conducted in the Afnor electrolyte solution. There was a decrease in the percentage of $\mathrm{Co}$ on the surface with the occurrence of oxygen and chlorine and sodium in the Afnor solution. All other elements, which form very stable oxides of corrosion, maintain their percentages around the initial alloy values. The distribution of surface chemical elements confirmed the formation of the stable oxide layer on the whole surface as well as the presence of salt deposits in the case of the Afnor artificial solution experiment.

\section{References}

1. BETTINI, E., LEYGRAF, C., LIN, C., LIU, P., PAN, J., J. Electrochem. Soc., 159, 2012, pp. C422-C427.

2. HAYAMA, A.O.F., ANDRADE, P.N., CREMASCO, A., CONTIERI, R.J ., AFONSO, C.R.M., CARAM, R., Mater. Des., 55, 2014, pp. 1006-1013. 3. LIU, C., ZHANG, E.,J. Mater. Sci. Mater. Med., 26, 2015, pp. 142.
4. BOLAT, G., MARECI, D., IACOBAN, S., CIMPOESU, N., MUNTEANU, C., J. Spectrosc., 2013, 2013, ID 714920.

5. MARECI, D., CIMPOESU, N., POPA, M. I., Mater. Corros., 63, 2012, pp. 176-180.

6. ZAHARIA, M., STANCIU S., CIMPOESU R., IONITA I., CIMPOESU N., Appl. Surf. Sci., 438, 2018, pp. 20-32.

7. CIMPOESU, N., SANDULACHE. F., ISTRATE, B., CIMPOESU, R, ZEGAN,

G., Metals, 8, 2018, pp. 541.

8. IZQUIERDO, J., BOLAT, G., CIMPOESU, N., TRINCA, L.C., MARECI,

D., SOUTO, R.M., Appl. Surf. Sci., 385, 2016, pp. 368-378.

9. CIMPOESU, N., TRINCA, L. C., DASCALU, G., STANCIU, S., GURLUI, S.O., MARECl, D., J. CHEM.(New York), 2016, 2016, Article ID 9520972. 10. BURLEA, S.L., CIMPOESU, N., AGOP, M., LEATA, R., Rev. Chim. (Bucharest), 67, 2016, p. 260-262.

11. YAMANAKA, K., MORI, M., CHIBA, A., Mater. Lett., 116, 2014, pp. 82-85.

12. ZHANG, E., LIU, C., Mater. Sci. Eng.: C. 69, 2016, pp. 134-143.

13. PETCU, A., NEMTOI, A., PASCA, S., SINDILAR, E.V., HABA, D., PETRARIU, F.D., Rev. Chim. (Bucharest), 66, no. 9, 2015, pp. 13311335.

14. TAKAICHI, A., SUYALATU, NAKAMOTO, T., J OKO, N., NOMURA, N., TSUTSUMI, Y., MIGITA, S., DOI, H., KUROSU, S., CHIBA, A., WAKABAYASHI, N., IGARASHI, Y., HANAWA, T., J. Mech. Behav. Biomed. Mater., 21, 2013, pp. 67-76.

15. BALAN, A., STOLERIU, S., ANDRIAN, S., SANDU, A.V., IOVAN, G., SERBAN-PINTILICIUC, V., Rev. Chim. (Bucharest), 66, no. 2, 2015, pp. 182-186.

16. OCRAN, E.K., GUENTHER, L.E., BRANDT, J.-M., WYSS, U., OJ O, O.A., Metall. Mater. Trans. A., 46, 2015, pp. 2696-2709.

17. VASILESCU, C., DROB, S., MORENO, J.C., OSICEANU, P., POPA, M., VASILESCU, E., MARCU, M., DROB, P., Corros. Sci., 93 2015, pp. 310323.

18. ASSIS, S.L.D., COSTA, I., Mater. Corros., 58, 2007, pp. 329-333.

19. PENDEFUNDA, A.A.C., MOCANU, C., FORNA, D.A., IORDACHE, C., LUCA, E., IFTENI, G., FORNA, C.N., Rev. Chim. (Bucharest), 69, no. 6, 2018, pp. 1598-1602.

20. POUND, B.G., J. Biomed. Mater. Res., 94, 2010, pp. 93-102.

21. EARAR, K., GRIGORE, C.A., BUDACU, C., TRINCA, L.C., MARECl, D., SINCAR, C.D., Rev. Chim. (Bucharest), 68, no. 2, 2017, p. 396-400. 22. GHIBAN, A., GHIBAN, B., PETER, I., ROSSO, M., DAN, I., TIGANESCU, T. V., Rev. Chim. (Bucharest), 67, no. 6, 2016, p. 11311136.

23. HSU, H.-C., WU, S.-C., HSU, S.-K., SUNG, Y.-C., HO, W.-F., Mater. Char., 62, 2011, pp. 157-163.

24. VITALARIU, A., LEATA, R., CHELARIU, R., MUNTEANU, C., CIMPOESU, R., ILIE, M., COMANECI, R., MOISEI, M., Rev. Chim. (Bucharest), 66, no. 12, 2015, p. 2147-2151.

25. FEKRY, A.M., Electrochim. Acta, 54, 2009, pp. 3480-3489.

26. NABIALEK, M., PIETRUSIEWICZ, P., SZOTA, M., ABDULLAH, M.M.A., SANDU, A.V., Rev. Chim. (Bucharest), 68, no. 1, 2017, p. 22-27.

27. MARECI, D., EARAR, K., ZETU, I., BOLAT, G., CRIMU, C., ISTRATE, B., MUNTEANU, C., MATEL, M.N., Mat. Plast., 52, no. 2, 2015, p. 150153.

28. GHIBAN, A., GHIBAN, B., SERBAN, N., TIGANESCU, T.V., Mat. Plast., 53, no. 4, 2016, p. 708-712.

$\overline{\text { Manuscript received: } 5.07 .2018}$ 